\title{
KANDUNGAN FOSFOR DAN KADMIUM PADA TANAH DAN BERAS SERTA RISIKO KADMIUM BAGI KESEHATAN PENDUDUK DI KELURAHAN TARUS
}

\author{
Yovita Yasintha Bolly \\ Vytayovieeta@gmail.com
}

\begin{abstract}
This research was conducted in Tarus Village, Kupang regency, in May until June 2013, to find out the amount of phosphorus and cadmium content in the soil of rice, and tocompare the $\mathrm{Cd}$ with a threshold concentration of Standard National Indonesia 7387:2009, as well as to predict the magnitude of the risk to the health. This research is descriptive experimental design with 12 samples of soil and rice.

Levels of soil-available $\mathrm{P}$ is analyzed using the methods of Olsen, whereas, the levels of $\mathrm{Cd}$ from the soil and rice are analyzed in the laboratory with the method of analysis of heavy metals in soils and plants, set by Hall of geochemical soil, the Ministry of agriculture. The results of the analysis of land-available Pranging from low - high, but it is not the only deciding factor the amount of $\mathrm{Cd}$ in soil and rice. Laboratory analysis results towards rice $\mathrm{Cd}$, shows there are six samples that undetectable levels of $\mathrm{Cd}$, six other samples detected and then described the risk once compared with the standard quality raw and analysis of health risks.

The results of the analysis of the levels of $\mathrm{Cd}$ shows all rice samples were still below standard quality raw i.e. $0,4 \mathrm{mg} \mathrm{kg}-1$. Risk analysis indicates that there are two samples of rice produced from the paddy fields are not safe for consumption for the duration of 30 years. While the four other samples were risk for the duration of the 60 years.
\end{abstract}

Keywords: phosphorus, cadmium and risk

\section{LATAR BELAKANG}

Tanah merupakan sumberdaya alam yang sangat penting untuk menunjang berbagai aktivitas kehidupan manusia. Salah satu aktivitas manusia yang bergantung pada tanah adalah kegiatan pertanian. Kerusakan tanah dapat dijumpai di Pulau Timor. Tanah pertanian di Pulau ini, sebagian besar tergolong tanah marginal dengan tingkat kesuburan tanah rendah, sehingga ketersediaan pangan secara kuantitas dan kualitas sulit terpenuhi (Duaja, 2006). Hal ini karena ketersediaan hara dalam tanah menjadi salah satu faktor pembatas produksi. Upaya yang dilakukan untuk mengatasi permasalahan ketersediaan hara adalah dengan memberikan input yang dapat menyediakan hara bagi tanaman.

Salah satu input modern yang digunakan dalam usaha tani untuk 
Yovita: Kandungan fosfor dan kadmium pada tanah dan beras serta risiko kadmium bagi kesehatan penduduk di kelurahan tarus

memenuhi kebutuhan hara dalam tanah adalah pupuk. Pupuk adalah segala bahan yang ditambahkan ke dalam tanah untuk meningkatkan kesuburan tanaman. Pupuk yang diberikan ke dalam tanah, saat ini pada umumnya adalah pupuk anorganik.

Seiring berjalannya waktu, pupuk anorganik yang ditambahkan dalam tanah dapat menimbulkan dampak terhadap penurunan kualitas tanah. Semakin tinggi intensitas pemakaian pupuk anorganik, tanpa adanya tindakan perbaikan lahan, maka semakin cepat pula terjadinya penurunan kualitas lahan, misalnya peningkatan kerapatan isi tanah, struktur tanah menjadi rusak, pencemaran tanah dan pencemaran badan-badan air oleh polutan dari pupuk tersebut.

Polutan yang dapat berada di dalam tanah antara lain fosfor $(\mathrm{P})$ dan kadmium $(\mathrm{Cd})$. Kedua unsur polutan tersebut dapat berada dalam tanah karena adanya pemakaian pupuk $\mathrm{P}$. Fosfor merupakan salah satu unsur hara esensial yang harus tersedia bagi tanaman. Fosfor berguna dalam merangsang pertumbuhan akar khususnya akar benih atau tanaman muda serta pembentukan anakan, pembungaan, pemasakan biji dan buah.
Jenis pupuk $\mathrm{P}$ yang biasa digunakan oleh petani antara lain TSP atau SP-36. Pupuk ini berasal dari batuan beku dan batuan endapan, mineral apatit dan ada yang berasal dari bahan-bahan organik, misalnya pupuk kandang kotoran sapi dan kotoran guano.

Penggunaan pupuk $\mathrm{P}$ di setiap musim tanam selama bertahun-tahun pada lahan pertanian dapat mengakibatkan terakumulasinya unsur tersebut di dalam tanah. Hal ini terjadi karena $\mathrm{P}$ tidak mudah larut dalam tanah. Sejalan aplikasi pupuk $\mathrm{P}$, diduga logam berat $\mathrm{Cd}$ juga terakumulasi dalam tanah, karenanya kekuatiran adanya kandungan logam berat dalam pupuk ini berkaitan dengan : (1) akumulasi Cd dalam tanah yang dalam jangka panjang akan berpengaruh pada kualitas dan kuantitas hasil tanaman; (2) serapan $\mathrm{Cd}$ dalam tanaman membahayakan kesehatan manusia dan ternak; dan (3) menurunkan kualitas tanah dan membahayakan keanekaragaman hayati dalam tanah.

Beberapa sumber menganjurkan penggunaan pupuk $\mathrm{P}$ yang mengandung Cd kurang dari $100 \mathrm{mg} \mathrm{kg}^{-1}$ dalam upaya mengurangi risiko penimbunan $\mathrm{Cd}$ di bagian tanaman yang dimakan (National Cd Minimisation Committee. 
Yovita: Kandungan fosfor dan kadmium pada tanah dan beras serta risiko kadmium bagi kesehatan penduduk di kelurahan tarus

2003). Namun perlu diingat bahwa waktu paruh $\mathrm{Cd}$ di dalam tanah adalah 100 sampai 1000 tahun (Senn and Milham, 2007) karena Cd sulit atau bahkan tidak dapat terurai dalam tanah (Adriano, 1986).

Dalam produk pertanian juga ditetapkan tingkat maksimum kandungan logam berat dan batas toleransi konsumsi harian logam berat ditetapkan sebesar $0,1 \mathrm{mg} \mathrm{kg}^{-1}$ berat basah hasil (Codex Alementarius Commission, 2001; Corrosion-doctors,), sedangkan menurut SNI 7387:2009, batas maksimum kandungan $\mathrm{Cd}$ dalam beras dan tepung beras adalah $0,4 \mathrm{mg}$ $\mathrm{kg}^{-1}$, selain itu ada juga penetapan toleransi asupan harian $\mathrm{Cd}$ oleh Program Bersama Standar Makanan FAO (Food Agriculture Organisation) / WHO (World Health Organisation) (Joint FAO/WHO Food Standard Program), untuk perempuan dewasa adalah $60 \mu \mathrm{g}$ hari $^{-1}$ dan untuk pria dewasa adalah $70 \mu \mathrm{g}$ hari $^{-1}$.

Beberapa penelitian terkait kandungan $\mathrm{Cd}$ dalam bahan pangan telah dilakukan, antara lain hasil penelitian yang dilakukan Sismiyati dkk (1993) menunjukkan bahwa beras jenis IR 64 yang dipasarkan di Bandung dan beras jenis Cisadane serta Saigon yang di pasarkan di Tangerang telah tercemar logam berat $\mathrm{Cd}$ masing-masing 0,24 mg $\mathrm{kg}^{-1}$ dan $0,33 \mathrm{mg} \mathrm{kg}^{-1}$. Bila konsumen beras per hari rata-rata $300 \mathrm{~g}$, maka berdasarkan hasil penelitian Suzuki (1980) dikutip Ratnaningsih (2003), kadar Cd yang masuk ke dalam tubuh 0,009 - 0,02 mg org ${ }^{-1}$ hari $^{-1}$. Sebagian besar $\mathrm{Cd}$ tersebut akan terakumulasi dalam hati dan ginjal sehingga kadarnya akan jauh lebih tinggi dari kadar $\mathrm{Cd}$ tersebut pada sumbernya dan ada yang keluar melalui pencernaan. Masukan (intake) Cd secara terus menerus akan membahayakan kesehatan manusia, karena dapat menyebabkan toksisitas kronis (Saeni, 1997). Kadmium jika dikonsumsi dapat mengakibatkan kerusakan pada ginjal, hati, paru-paru dan tulang (Alloway and Ayres, 1993; Slamet, 2002; Rawat et al, 2012).

Kadmium yang masuk ke dalam tubuh terkumpul di dalam ginjal, hati dan ada sebagian yang dikeluarkan lewat saluran pencernaan (Pratiwi dkk, 2008). Secara umum gejala keracunan Cd pada manusia baik secara akut maupun kronis dapat mengakibatkan gangguan pada sistem pernapasan, kerusakan pada fungsi organ hati dan ginjal, pendarahan, gangguan terhadap 
Yovita: Kandungan fosfor dan kadmium pada tanah dan beras serta risiko kadmium bagi kesehatan penduduk di kelurahan tarus

pertumbuhan tulang yang menyebabkan kerapuhan tulang.

Penggunaan pupuk anorganik terjadi pada petani-petani yang berada di Kelurahan Tarus Kabupaten Kupang. Dalam satu musim tanam, petani di daerah ini melakukan pemupukan sebanyak dua kali, yaitu sebelum penanaman dan 21 hari setalah penanaman. Jenis pupuk yang diberikan umunya Urea, TSP dan KCl. Pada tahap awal, pupuk yang diberikan adalah Urea dan TSP, sedangkan pada tahap kedua Urea dan KCl. Pupuk akan ditambahkan apabila saat pertumbuhan dan perkembangannya, padi menunjukkan gejala-gejala kekurangan unsur hara. Tidak terdapat dosis pupuk anjuran pada petani di daerah tersebut, karena apabila petani mempunyai ekonomi yang cukup, maka akan menambah dosis pupuk pada lahan pertaniannya.

Kebutuhan beras penduduk Kabupaten Kupang secara khusus, dan Kota Kupang pada umumnya dipasok dari daerah ini. Pola tanam padi di Kelurahan Tarus adalah sawah irigasi yang mengandalkan air dari mata air di sekitar lahan. Keberadaan mata air yang tidak pernah kering pada musim kemarau ini, mengakibatkan para petani dapat mengusahakan sawahnya dua kali dalam satu tahun. Pertanian pada lahan sawah tersebut tidak ada sistem bera, karena setelah selesai panen padi, sawah tersebut ditanami sayur-sayuran dan diberi pupuk. Berdasarkan pemikiranpemikiran tersebut, maka peneliti merasa perlu mendapatkan informasi tentang kandungan $\mathrm{P}$ dan $\mathrm{Cd}$ pada tanah dan beras serta risiko Cd bagi kesehatan penduduk di Kelurahan Tarus Kabupaten Kupang.

\section{METODE PENELITIAN}

\section{Tempat dan Waktu Pelaksanaan Penelitian}

Lokasi penelitian ini dilaksanakan di Lahan Sawah Kelurahan Tarus Kabupaten Kupang. Analisis tanah dan beras dilakukan di Laboratorium Kimia Fakultas Pertanian Universitas Nusa Cendana dan Laboratorium Badan Lingkungan Hidup Daerah NTT. Penelitian ini dilaksanakan pada bulan Mei 2013.

\section{Alat dan Bahan}

Alat yang digunakan adalah Neraca analitik, botol kocok $100 \mathrm{ml}$, dispenser $50 \mathrm{ml}$ gelas ukur, mesin pengocok, labu semprot $500 \mathrm{ml}, \mathrm{pH}$ meter, alat penghalus sampel tanah dan tanaman, alat penyaring, alat penyimpan sampel, labu ukur, pipet volumetric, 
Yovita: Kandungan fosfor dan kadmium pada tanah dan beras serta risiko kadmium bagi kesehatan penduduk di kelurahan tarus

pipet ukur, gelas piala, Erlenmeyer, neraca analitik, Spektrofotometer serapan atom (AAS), corong gelas, pemanas listrik, alat saring vakum, saringan membrane, timbangan analitik, labu semprot, $\mathrm{pH}$ meter,mesin pengocok, dan timbangan berat badan. Sedangkan bahan yang digunakan adalah Tanah kering udara (BTKU) dari lapangan, sampel beras, $\mathrm{HCl}, \mathrm{HNO}_{3}$, aquades, larutan pengencer, larutan pencuci dan bahan kimia lainnya.

\section{Variabel Pengamatan}

Variabel Utama yang akan diamati dalam penelitian adalah kandungan $\mathrm{P}$ pada tanah sawah, kandungan $\mathrm{Cd}$ pada tanah sawah, kandungan $\mathrm{Cd}$ pada beras, serta tingkat risiko kesehatan penduduk akibat konsumsi beras dari Kelurahan Tarus Kabupaten Kupang. Variabel pendukung yang akan diamati adalah pH Tanah, C-organik tanah, P-total tanah dan kandungan $\mathrm{Cd}$ dalam pupuk $\mathrm{P}$ yang digunakan oleh petani di Kelurahan Tarus.

\section{Teknik analisis data}

Pengolahan data menggunakan perhitungan analisis risiko yaitu dengan menghitung asupan (intake), untuk mengetahui seberapa besar risikonya terhadap konsumen. Perhitungan asupan (intake) didapat berdasarkan data konsentrasi risk agent $\left(\mathrm{C}, \mathrm{mg} \mathrm{kg}^{-1}\right)$, laju asupan atau konsumsi( $\mathrm{R}, \mathrm{kg}$ hari $\left.{ }^{-1}\right)$, frekuensi pajanan tahunan $\left(\mathrm{f}_{\mathrm{E}}\right.$, hari tahun $\left.^{-1}\right)$, durasi pemaparan $\left(D_{t}\right)$ dalam tahun menggunakan 30 tahun untuk nilai default, berat badan $\left(\mathrm{W}_{\mathrm{b}}, \mathrm{kg}\right)$, periode waktu rata-rata $\left(\mathrm{t}_{\mathrm{avg}} 30\right.$ tahun $\mathrm{x}$ 365 hari/tahun untuk nonkarsinogen).

Analisis data untuk memprediksi besar dampak kontaminasi Cd bagi manusia, menggunakan metode Public Health Assesment (PHA) (ATSDR, 2005). Metode PHA dilaksankaan sebagai berikut:

$$
I=\frac{C \times R \times f_{\mathrm{E}} \times D_{\mathrm{t}}}{W_{\mathrm{b}} \times t_{\mathrm{avg}}}
$$

Setelah didapat nilai asupan (I), maka dicari nilai asupan konsentrasi risk agent maksimum $(R Q)=\mathrm{I} / R f D$. Bila ternyata $R Q>1$ berarti ada risiko potensial sedangkan bila $R Q<1$ untuk sementara pencemaran masih aman dan belum perlu dikendalikan.

\section{Pembahasan}

\section{Kadmium Pada Tanah}

Kadmium adalah logam berat yang sangat berbahaya bagi kesehatan manusia. Di Jepang, sumber utama terserapnya $\mathrm{Cd}$ oleh manusia adalah dari padi dan kontaminasi $\mathrm{Cd}$ pada 
Yovita: Kandungan fosfor dan kadmium pada tanah dan beras serta risiko kadmium bagi kesehatan penduduk di kelurahan tarus

tanah sawah. Selain Jepang, Cina dan Thailand mengalami masalah dengan adanya kontaminasi $\mathrm{Cd}$ pada padi (Uraguchi dan Fujiwara, 2012). Kadmium yang masuk ke dalam tubuh akan terakumulasi, sehingga kadarnya akan jauh lebih tinggi dari kadar logam berat tersebut pada sumbernya. Hal ini membahayakan kesehatan manusia, karena dapat menyebabkan toksisitas kronis bila dikonsumsi terus-menerus.
Salah satu sumber Cd yang dapat membawa $\mathrm{Cd}$ ke dalam tubuh manusia adalah melalui nasi (beras). Hal ini terjadi karena $\mathrm{Cd}$ tidak dapat hilang melalui proses pemanasan (beras dimasak), bahkan dengan adanya pemanasan dapat meningkatkan konsentrasinya di dalam beras. Berikut disajikan hasil analisis $\mathrm{Cd}$ pada tanah sawah di Kelurahan Tarus pada tabel 4.3 di bawah.

Tabel 4.3. Kadar Cd Pada Tanah Sawah Dari Kelurahan Tarus

\begin{tabular}{ccc}
\hline NO & KODE SAMPEL & KONSENTRASI Cd $\left(\mathrm{mg} \mathrm{kg}^{-1}\right)$ \\
\hline 1 & TB1 & 0.77 \\
2 & TB2 & 0.69 \\
3 & TB3 & 0.54 \\
4 & TB4 & 1.56 \\
5 & TT1 & 0.70 \\
6 & TT2 & 0.36 \\
7 & TT3 & 0.10 \\
8 & TT4 & 0.31 \\
9 & TA1 & 0.37 \\
10 & TA2 & 1.79 \\
11 & TA3 & 1.12 \\
12 & TA4 & 1.35 \\
\hline
\end{tabular}

Sumber : Hasil Analisis Pada Laboratorium BLHD-NTT (2013)

Kandungan $\mathrm{Cd}$ dalam tanah esensial dan pada tingkat tertentu dapat berkisar antara 0,01 sampai dengan 7,00 menimbulkan keracunan (Charlena, $\mathrm{mg} \mathrm{kg}{ }^{-1}$ (Pendias, 2000 dikutip IPB, 2004). Berdasarkan tabel di atas terlihat 2006). Tanah merupakan bagian dari dengan jelas kandungan $\mathrm{Cd}$ yang ada siklus logam berat, termasuk $\mathrm{Cd}$. dalam tanah sawah di Kelurahan Tarus Masuknya Cd ke dalam tanah apabila Kabupaten Kupang. Kandungan Cd melebihi kemampuan tanah dalam tertinggi terdapat pada sampel $\mathrm{TA}_{1}$, mencerna limbah tersebut dapat $\mathrm{TB}_{4}, \mathrm{TA}_{4}, \mathrm{TA}_{3}$ dan $\mathrm{TB}_{1}$ yaitu masingmengakibatkan pencemaran tanah. masing $1,79 \mathrm{mg} \mathrm{kg}^{-1}, 1,56 \mathrm{mg} \mathrm{kg}^{-1}, 1,35$ Kadmium merupakan logam non $\mathrm{mg} \mathrm{kg}{ }^{-1}, 1,12 \mathrm{mg} \mathrm{kg}{ }^{-1}, 0,77 \mathrm{mg} \mathrm{kg}{ }^{-1}$. 
Yovita: Kandungan fosfor dan kadmium pada tanah dan beras serta risiko kadmium bagi kesehatan penduduk di kelurahan tarus

Sampel dengan kandungan Cd terendah terdapat pada sampel $\mathrm{TT}_{3}$ yaitu $0,10 \mathrm{mg}$ $\mathrm{kg}^{-1}$.

Kadmium dalam tanah dapat dipilah menjadi beberapa bentuk atau fraksi, yaitu larut dalam air atau berada dalam larutan tanah, tertukarkan atau terikat pada tapak-tapak jerapan pada koloid tanah dan dapat dibebaskan oleh reaksi pertukaran kation, terikat dengan senyawa organik dan berasosiasi dengan senyawa humus yang tidak terlarutkan, dan terjerat dalam oksida besi dan mangan. Namun, walaupun kandungan Cd dalam larutan tanah rendah, jika dilihat dari segi ekologi, bentuk ini paling penting karena penyerapan tanaman dan pengangkutan dalam lingkungan bergantung padanya. Di Indonesia belum ada nilai batas maksimum $\mathrm{Cd}$ yang diperbolehkan dalam tanah, namun pada beberapa negara di dunia telah menetapkan kandungannya, yaitu $5 \mathrm{mg} \quad \mathrm{kg}$ ${ }^{1}$ (Austria), $8 \mathrm{mg} \mathrm{kg-}^{1}$ (Kanada), $50 \mathrm{mg}$ $\mathrm{kg-}^{1}$ (Polandia), $3 \mathrm{mg} \mathrm{kg-}^{1}$ (Inggris) dan di Jepang 2 mg kg- $^{1}$ (KabataPendias, 1995).

\section{Kadmium Pada Beras}

Pangan yang dikonsumsi seharihari merupakan hasil pertanian. Pangan seharusnya memenuhi kriteria ASUH
(Aman, sehat, utuh dan halal). Salah satu parameter tersebut yaitu aman, termasuk dalam masalah mutu. Mutu dan keamanan pangan berpengaruh langsung terhadap kesehatan masyarakat. Beras merupakan sumber pangan utama bagi manusia, oleh karena itu higienitas dan keamanan beras yang dikonsumsi menjadi sangat penting agar tidak menimbulkan gangguan kesehatan.

Setelah melakukan analisis pada tanah sawah di Kelurahan Tarus, tanah tersebut mengandung $\mathrm{Cd}$ dengan dosis yang berbeda. Apabila tanah sebagai media tanam telah mengandung $\mathrm{Cd}$, maka tidak dipungkiri bahwa tanaman yang dibudidayakan pada tanah tersebut akan menyerap $\mathrm{Cd}$, sehingga beras yang dihasilkan dari lahan tersebut juga mengandung $\mathrm{Cd}$ yang berbahaya bagi makhluk hidup, khususnya manusia yang mengkonsumsinya.

Untuk analisis beras, peneliti mengambil sampel beras sesuai dengan titik sampel tanah (berbeda pemilik lahan), sehingga terdapat 12 sampel beras yang berasal dari lahan sawah tersebut. Berikut disajikan hasil analisis Cd beras pada tabel 4.4 di bawah ini.

Berdasarkan hasil analisis $\mathrm{Cd}$ terhadap beras yang berasal dari lahan 
Yovita: Kandungan fosfor dan kadmium pada tanah dan beras serta risiko kadmium bagi kesehatan penduduk di kelurahan tarus

sawah di Kelurahan Tarus menunjukkan kandungan beberapa sampel beras tidak terdeteksi pada alat analisis kandungan logam berat (AAS) hal ini terjadi karena kandungan $\mathrm{Cd}$ berada dibawah kemampuan deteksi alat, namun apabila dihubungkan antara kandungan logam berat pada tanah dan tanaman sangat mempunyai hubungan, karena apabila
Cd dalam tanah rendah (sedikit) maka Cd yang diserap tanamanpun rendah, yaitu pada sampel tanah $\mathrm{TB}_{1}, \mathrm{~TB}_{2}, \mathrm{~TB}_{3}$, $\mathrm{TT}_{1}, \mathrm{TT}_{3}$ dan $\mathrm{TT}_{4}$ mengandung $\mathrm{Cd}$ dalam tanah yang rendah hal ini menyebabkan kadar $\mathrm{Cd}$ dalam beras tidak terdeteksi pula pada sampel beras dengan kode $\mathrm{BB}_{1}, \mathrm{BB}_{2}, \mathrm{BB}_{3}, \mathrm{BT}_{1}, \mathrm{BT}_{3}$ dan $\mathrm{BT}_{4}$ (lihat tabel 4.3)

Tabel 4.4. Kadar Cd pada beras

\begin{tabular}{cccc}
\hline NO & Kode Sampel & Konsentrasi Cd $\left(\mathrm{mg} \mathrm{kg}^{-1}\right)$ & Standar SNI $\left(\mathrm{mg} \mathrm{kg}^{-1}\right)$ \\
\hline 1 & BB1 & TD & 0.4 \\
2 & BB2 & TD & 0.4 \\
3 & BB3 & TD & 0.4 \\
4 & BB4 & $5 \times 10^{-2}$ & 0.4 \\
5 & BT1 & TD & 0.4 \\
6 & BT2 & $15 \times 10^{-2}$ & 0.4 \\
7 & BT3 & TD & 0.4 \\
8 & BT4 & TD & 0.4 \\
9 & BA1 & $19 \times 10^{-2}$ & 0.4 \\
10 & BA2 & $5 \times 10^{-2}$ & 0.4 \\
11 & BA3 & $5.1 \times 10^{-2}$ & 0.4 \\
12 & BA4 & $4.8 \times 10^{-2}$ & 0.4 \\
\hline \multicolumn{4}{r}{ Sumber $\cdot$ Hasil Analisis Pad Laboraborium BLHD-NTT $(2013)$}
\end{tabular}

Berdasarkan hasil analisis ditemukan kandungan $\mathrm{Cd}$ yang berbeda, tersebut, serapan Cd oleh tanaman tidak karena hal ini dipengaruhi oleh sejalan $\mathrm{pH}$ tanah, C-organik dan $\mathrm{P}$ perbedaan genotipenya (Cheng et al, tersedia tanah, karena terdapat pada beberapa sampel tanah mengandung $\mathrm{C}$ organik tanah yang tinggi, namun serapan Cd pada tanaman tinggi. Mench (1998) mengemukakan bahwa sayuran daun dan umbi kentang mengakumulasi Cd dalam jumlah yang lebih banyak dari pada buah-buahan dan biji-bijian. Tanaman yang samapun dapat 2006).

\section{Analisis Risiko}

\section{Analisis Pemaparan}

Analisa pemaparan dilakukan untuk menentukan dosis risk agent $\mathrm{Cd}$ yang diterima individu sebagai asupan atau intake (I). Nilai Frekuensi pajanan ( $\left.f_{E}\right)$ diperoleh dari nilai default yaitu dengan pertimbangan pemilik lahan 
Yovita: Kandungan fosfor dan kadmium pada tanah dan beras serta risiko kadmium bagi kesehatan penduduk di kelurahan tarus

sawah yang termasuk dalam Kelompok

Rukun Tani yang berada di daerah Tarus tergolong dalam penduduk menetap, maka dipakai nilai default untuk menghitung laju asupan yakni sebesar 350 hari per tahun. Untuk durasi pajanan (Dt) nilai yang dipakai berdasarkan nilai default golongan residensial, yakni 30 tahun. Untuk managemen risiko, maka durasi pajanan dapat diperpendek menjadi 5 tahun dan 10 tahun, atau lebih. Nilai $\mathrm{Wb}$ (berat badan) untuk rata-rata orang Indonesia yang dijadikan nilai default adalah 55 $\mathrm{kg}$.

Dalam prediksi risiko ini, telah dilakukan pengukuran berat badan para responden yang mengkonsumsi beras dari sawah di Tarus. Data tersebut akan dipakai dalam managemen risiko, yakni menggunakan berat badan yang paling banyak frekuensinya. Berat badan tersebut adalah $40 \mathrm{~kg}, 45 \mathrm{~kg}, 50 \mathrm{~kg}$ dan $55 \mathrm{~kg}$. Nilai laju asupan (R) maka dari hasil wawancara dan pengukuran di lapangan, maka diketahui jumlah nasi yang dikonsumsi responden terbanyak adalah $581,1 \mathrm{~g}$ atau $0,584 \mathrm{~kg}$ nasi. Untuk jenis asupan sesuai dengan tetapan yang telah dibuat untuk $\mathrm{Cd}$ adalah bahwa unsur tersebut termasuk dalam golongan non karsinogenik $\left(\mathrm{I}_{\mathrm{nk}}\right)$ dengan frekuensi paparan 30 tahun $\mathrm{x}$ 365 hari/tahun (nilai $t_{a v g}$ ).

Keseluruhan nilai prediksi risiko dari adanya konsentrasi $\mathrm{Cd}$ pada beras yang dihasilkan dari tanah sawah di Kelurahan Tarus dapat dilihat pada tabel 4.4 prediksi risiko $\mathrm{Cd}$. Variabelvariabel yang digunakan dalam prediksi risiko ini menggunakan nilai default, hanya konsentrasi $\mathrm{Cd}$ yang merupakan hasil analisis labarotorium.

Tabel 4.5. Prediksi Risiko Cd di Beras

\begin{tabular}{cccccc}
\hline NO & $\begin{array}{c}\text { Kode } \\
\text { Sampel }\end{array}$ & $\begin{array}{c}\text { Konsentrasi Cd } \\
\left(\mathrm{mg} \mathrm{kg}^{-1}\right)\end{array}$ & $\begin{array}{c}\text { Standar SNI } \\
2009\left(\mathrm{mg} \mathrm{kg}^{-1}\right)\end{array}$ & $\begin{array}{c}\mathrm{I}_{\mathrm{nk}} \\
\text { default }\end{array}$ & $\begin{array}{c}\text { RQ } \\
\text { default }\end{array}$ \\
\hline & & & & & \\
1 & BB1 & TD & 0.4 & - & - \\
2 & BB2 & TD & 0.4 & - & - \\
3 & BB3 & TD & 0.4 & - & - \\
4 & BB4 & $5 \times 10^{-2}$ & 0.4 & $5 \times 10^{-4}$ & 0.51 \\
5 & BT1 & TD & 0.4 & - & - \\
6 & BT2 & $15 \times 10^{-2}$ & 0.4 & $15 \times 10^{-4}$ & 1.49 \\
7 & BT3 & TD & 0.4 & - & - \\
8 & BT4 & TD & 0.4 & - & - \\
9 & BA1 & $19 \times 10^{-2}$ & 0.4 & $20 \times 10^{-4}$ & 1.97 \\
10 & BA2 & $5 \times 10^{-2}$ & 0.4 & $5 \times 10^{-4}$ & 0.51 \\
11 & BA3 & $5.1 \times 10^{-2}$ & 0.4 & $5.2 \times 10^{-4}$ & 0.52 \\
12 & BA4 & $4.8 \times 10^{-2}$ & 0.4 & $4,9 \times 10^{-2}$ & 0.49 \\
\hline
\end{tabular}


Yovita: Kandungan fosfor dan kadmium pada tanah dan beras serta risiko kadmium bagi kesehatan penduduk di kelurahan tarus

Tingkat risiko dari konsentrasi $\mathrm{Cd}$ yang ada dalam beras dari Kelurahan Tarus Kabupaten Kupang, jika dibandingkan dengan Standar Nasional Indonesia (SNI) maka terdapat empat sampel beras yang masih berada di bawah standar kelayakan yang ditetapkan oleh Badan Standardisasi Nasional (BSN) yang ditetapkan karena nilai default masa waktu 30 tahun menunjukkan RQ lebih kecil daru satu, namun kadar $\mathrm{Cd}$ pada dua sampel lainnya menunjukkan bahwa beras tersebut telah berisiko untuk dikonsumsi (nilai rq lebih besar dari satu. Risiko tersebut ditunjukan oleh batasanbatasan yang ada, baik baku mutu di SNI maupun nilai RQ.

Risiko yang ditimbulkan $\mathrm{Cd}$ yang ada pada beras ini ditunjukan oleh nilai RQ yang lebih besar dari 1 (RQ > 1). Kadmium yang berisiko ini, sangat berbahaya ketika telah masuk ke dalam tubuh. WHO (1992) melaporkan pada penderita ita-itai diperkirakan $\mathrm{Cd}$ telah menyebabkan gangguan pada tulang. Palar (2004) mengemukakan bahwa keracunan kronis yang disebabkan oleh Cd dapat mengakibatkan penyakit anemia, hal ini ditemukan pada para pekerja yang telah bekerja selama 5-30 tahun pada industri-industri di Amerika. selain itu pajanan debu Cd selama 20 tahun oleh para pekerja tersebut telah menyebabkan terjadinya pembengkakan paru-paru.

Kerusakan paru-paru juga terjadi pada para pekerja pabrik perhiasan di Amerika Serikat yang selalu menghirup asap dan bubuk $\mathrm{Cd}$ selama bekerja di pabrik tersebut (Wittman and $\mathrm{Hu}$, 2002). Hal ini dikarenakan $\mathrm{Cd}$ yang beracun ini tidak hilang dari tubuh melalui paru-paru ketika bernapas, dan tidak hilang dari tubuh ketika makanan atau air terbuang dari tubuh melalui feses (ATSDR, 1999). Akibatnya, Cd akan terbawa ke dalam hati dan ginjal dan tertimbun selama bertahun-tahun. Hal inilah yang dapat mengakibatkan timbulnya penyakit hingga kematian karena toksisitas kronis dari $\mathrm{Cd}$.

\section{Interpretasi risiko}

Berdasarkan estimasi risiko di atas, Cd yang terdapat dalam beras sangat berisko bagi individu dengan berat badan $55 \mathrm{~kg}$ bila beras ( nasi) tersebut dikonsumsi sebanyak 0,584 $\mathrm{kg} /$ hari selama 350 hari/tahun dalam jangka waktu 30 tahun karena RQ jauh di atas 1. Estimasi tersebut dihitung untuk durasi default sepanjang hayat (lifetime) 30 tahun sehingga efek-efek toksisitas $\mathrm{Cd}$ mungkin baru dirasakan 
Yovita: Kandungan fosfor dan kadmium pada tanah dan beras serta risiko kadmium bagi kesehatan penduduk di kelurahan tarus

dalam masa 30 tahun ke depan. Hal ini dapat terlihat pada sampel beras T6 dan T9, karena menunjukkan nilai RQ jauh di atas satu.

Untuk pembuktian, 30 tahun bukan jangka waktu survei yang normal. Karena itu perlu dihitung estimasi risiko untuk durasi pajanan real time yang dialami penduduk. Sehingga dalam interpretasi risiko ini, digunakan jangka waktu yang lebih pendek yakni 10 tahun, 20 tahun dan 40 tahun. Dengan adanya informasi prediksi risiko dalam kurun waktu yang lebih pendek atau lebih dari durasi default ini, diharapkan dapat meningkatkan tingkat kewaspadaan terhadap risiko paparan kontaminan tersebut. Dapat dilihat pada tabel 4.6 Interpretasi risiko Cd di bawah ini.

Tabel 4.6 Interpretasi risiko Cd jangka waktu 10, 20, dan 40,50dan 60 Tahun

\begin{tabular}{|c|c|c|c|c|c|c|c|c|c|c|c|}
\hline Sampel & Kadar & Ink 10 & $\begin{array}{c}\text { RQ } \\
10\end{array}$ & Ink 20 & $\begin{array}{c}\text { RQ } \\
20\end{array}$ & Ink 40 & $\begin{array}{c}\text { RQ } \\
40\end{array}$ & Ink 50 & $\begin{array}{c}\text { RQ } \\
50\end{array}$ & Ink 60 & $\begin{array}{c}\text { RQ } \\
60\end{array}$ \\
\hline BA4 & $5 \times 10^{-2}$ & $\begin{array}{r}2 \times 10^{-} \\
4\end{array}$ & 0.2 & $3 \times 10^{-4}$ & 0.3 & $7 \times 10^{-4}$ & 0.7 & $9 \times 10^{-4}$ & 0.9 & $10 \times 10^{-4}$ & 1.0 \\
\hline BT2 & $15 \times 10^{-2}$ & $\begin{array}{r}5 \times 10^{-} \\
4\end{array}$ & 0.5 & $10 \times 10^{-4}$ & 1.0 & $\begin{array}{r}20 \times 10^{-} \\
4\end{array}$ & 2.0 & $\begin{array}{c}25 \times 10^{-} \\
4\end{array}$ & 2.5 & $30 \times 10^{-4}$ & 3.0 \\
\hline BA1 & $19 \times 10^{-2}$ & $\begin{array}{r}7 \times 10^{-} \\
4\end{array}$ & 0.7 & $13 \times 10^{-4}$ & 1.3 & $\begin{array}{r}26 \times 10^{-} \\
4\end{array}$ & 2.6 & $\begin{array}{c}33 \times 10^{-} \\
4\end{array}$ & 3.3 & $39 \times 10^{-4}$ & 3.9 \\
\hline BA2 & $5 \times 10^{-2}$ & $\begin{array}{r}2 \times 10^{-} \\
4\end{array}$ & 0.2 & $3 \times 10^{-4}$ & 0.3 & $7 \times 10^{-4}$ & 0.7 & $9 \times 10^{-4}$ & 0.9 & $10 \times 10^{-4}$ & 1.0 \\
\hline BA3 & $5.1 \times 10^{-2}$ & $\begin{array}{r}2 \times 10^{-} \\
4\end{array}$ & 0.2 & $3 \times 10^{-4}$ & 0.3 & $7 \times 10^{-4}$ & 0.7 & $9 \times 10^{-4}$ & 0.9 & $10 \times 10^{-4}$ & 1.0 \\
\hline BA4 & $4.8 \times 10^{-2}$ & $\begin{array}{r}2 \times 10^{-} \\
4\end{array}$ & 0.2 & $3 \times 10^{-4}$ & 0.3 & $7 \times 10^{-4}$ & 0.7 & $8 \times 10^{-4}$ & 0.8 & $10 \times 10^{-4}$ & 1.0 \\
\hline
\end{tabular}

Berdasarkan tabel 4.6. di atas dapat dilihat bahwa terdapat perubahan batasan aman ketika durasi waktu diubah. Prediksi risiko dengan durasi waktu 30 tahun (default) memberi informasi bahwa, dua sampel beras di Kelurahan Tarus Kabupaten Kupang telah berisiko untuk dikonsumsi.
Sampel beras yang diuji unsur Cd dan berisiko tersebut, kemudian diperkecil hingga durasi waktu 10 tahun dan 20 tahun. Untuk durasi waktu 10 tahun hasilnya menunjukan bahwa beras dari persawahan di Kelurahan Tarus belum berisiko karena adanya kontaminan $\mathrm{Cd}$, karena memiliki nilai RQ jauh di atas satu, sedangkan untuk 
Yovita: Kandungan fosfor dan kadmium pada tanah dan beras serta risiko kadmium bagi kesehatan penduduk di kelurahan tarus

durasi waktu 20 tahun ternyata sampel beras T6 dan T9 seharusnya sudah sudah berisiko tanpa menunggu waktu default yaitu 30 tahun, karena nilai RQ dari sampel beras tersebut sudah menunjukkan nilai satu. Mengingat hingga durasi waktu default masih terdapat sampel beras yang belum beisiko, maka peneliti memperpanjang perhitungan risiko dari waktu default yaitu 40, 50 dan 60 tahun. Ternyata pada durasi waktu hingga 60 tahun, empat sampel beras yang awalnya hingga durasi waktu 40 dan 50 tahun belum berisiko, sudah menunjukkan nilai RQ di atas satu. Hal ini tentu saja akan berisiko terhadap kesehatan masayakat yang mengkonsumsi beras tersebut. Informasi tentang durasi waktu ini, masih bersifat umum untuk dijadikan acuan dalam melakukan survei epidemologi. Hal ini dikarenakan, durasi waktu risiko tersebut masih berupa range waktu yang cukup panjang. Karena itu diperlukan durasi waktu yang lebih spesifik lagi untuk mempermudah dilakukannya survei epidemologi.

\section{Durasi waktu untuk dilakukan survei} epidemologi

Survei epidemologi ini berfungsi untuk menentukan batasan waktu untuk dilakukannya survei agar dapat menemukan gejala atau penyakit yang ditimbulkan karena mengkonsumsi beras yang terkontaminasi Cd. Agar survei ini dapat tepat waktu dan sasaran, maka dapat dihitung dengan persamaan sebagai berikut:

$$
\mathrm{Dt}=\frac{R f D x W b x t_{a v g}}{C x R x f_{E}}
$$

Hasil perhitungan waktu survei tersebut dapat dilihat pada tabel 4.7.

Tabel Batas Durasi Waktu Untuk Dilakukan Survei Epidemologi

\begin{tabular}{cccc}
\hline Sampel & $\begin{array}{c}\text { Konsentrasi } \\
\left(\mathbf{m g ~ k g}^{-\mathbf{1}}\right)\end{array}$ & RQ default & $\begin{array}{c}\text { Batas Dt } \\
\text { (tahun) }\end{array}$ \\
\hline BA4 & $5 \times 10^{-2}$ & 0.51 & 58.33 \\
BT2 & $15 \times 10^{-2}$ & 1.49 & 20.14 \\
BA1 & $19 \times 10^{-2}$ & 1.97 & 15.21 \\
BA2 & $5 \times 10^{-2}$ & 0.51 & 58.78 \\
BA3 & $5.1 \times 10^{-2}$ & 0.52 & 57.55 \\
BA4 & $4.8 \times 10^{-2}$ & 0.49 & 61.42 \\
\hline
\end{tabular}


Yovita: Kandungan fosfor dan kadmium pada tanah dan beras serta risiko kadmium bagi kesehatan penduduk di kelurahan tarus

Berdasarkan tabel batas durasi waktu untuk dilakukan survei epidemologi dapat dilihat bahwa waktu paparan kontaminan $\mathrm{Cd}$ harus mulai dikendalikan. Bila dibandingkan hasil perhitungan nilai RQ pada tabel 4.5 dan 4.6 maka dapat terlihat terdapat perbedaan waktu durasi paparan $\mathrm{Cd}$ pada beras hingga berisiko terhadap kesehatan, misalnya sampel berkode T9 pada tabel 4.5 memberikan informasi bahwa beras tersebut telah berisiko ketika mencapai durasi waktu hingga 20 tahun. Setelah dilakukan prediksi durasi pemaparan lamanya risiko pada tabel 4.6 menunjukkan bahwa durasi waktu yang lebih spesifik pada sampel beras yakni risikonya sudah dimulai pada durasi waktu 15,21 tahun. Sehingga dengan adanya survei dengan informasi seperti ini diharapkan dapat meminimalkan risiko paparan $\mathrm{Cd}$ pada beras yang didapat karena lebih tepat waktu dan sasaran.

\section{Managemen Risiko}

Beberapa pilihan manajemen risiko dirumuskan tanpa mengurangi (menurunkan) konsentrasi $\mathrm{Cd}$ dalam beras yang menjadi baku mutu pangan (beras). Managemen risiko ini dibuat untuk mengetahui jumlah beras (nasi) yang seharusnya dikonsumsi oleh para masyarakat setiap harinya. Jumlah beras (nasi) yang dikonsumsi ini, disesuaikan dengan berat badan yang ada. Dalam pembahasan ini, managemen risiko dibuat dari kisaran berat badan konsumen beras (nasi) yang menjadi sampel penelitian. Berat badan tersebut adalah yang paling banyak ditemukan dari para konsumen yaitu $40 \mathrm{~kg}, 45 \mathrm{~kg}$ dan $50 \mathrm{~kg}$ dan $55 \mathrm{~kg}$. Sehingga managemen risiko ini menggunakan persamaan:

$$
\mathrm{R}=\frac{R f D x W b x t_{\text {avg }}}{C x f_{E} x D t}(k g / \text { hari })
$$

Persamaan di atas, dapat memberi informasi tentang beras (nasi) yang seharusnya dikonsumsi setiap harinya oleh para konsumen, dengan memanfaatkan nilai RfD yang telah ditetapkan untuk $\mathrm{Cd} \quad\left(\begin{array}{lll}1 & \mathrm{x} & 10^{-3}\end{array}\right)$, konsentrasi kadmium sesuai hasil analisis, frekuensi paparan sesuai nilai default serta durasi waktu default. Maka informasi yang diperoleh adalah seperti yang tersaji pada tabel 4.8.

Berdasarkan tabel 4.8 tersebut di atas maka terlihat hubungan konsentrasi $\mathrm{Cd}$, tingkat risiko dan banyaknya beras yang harus dikonsumsi, yaitu hubungan berat badan dan banyaknya nasi yang dapat dikonsumsi. Semakin bertambah 
Yovita: Kandungan fosfor dan kadmium pada tanah dan beras serta risiko kadmium bagi kesehatan penduduk di kelurahan tarus

berat badan individu, maka tingkat risiko ketika mengkonsumsi beras (nasi) dengan kadar $\mathrm{Cd}$ yang sama lebih rendah dari orang yang memiliki berat badan yang lebih kecil. Jadi semakin bertambah berat badan seseorang maka beras (nasi) yang dikonsumsipun dapat semakin banyak, dengan tingkat risiko yang lebih kecil.

Tabel 4.8 Banyaknya beras anjuran untuk dikonsumsi $\left(\mathrm{kg} \mathrm{hari}^{-1}\right)$

\begin{tabular}{ccccccc}
\hline Sampel & Konsentrasi & RQ default & R 40 & R 45 & R 50 & R 55 \\
\hline BA4 & $5 \times 10^{-2}$ & 0.51 & 0.825757 & 0.9289771 & 1.032197 & 1.1354165 \\
BT2 & $15 \times 10^{-2}$ & 1.49 & 0.285137 & 0.3207789 & 0.356421 & 0.3920631 \\
BA1 & $19 \times 10^{-2}$ & 1.97 & 0.215363 & 0.2422836 & 0.269204 & 0.2961244 \\
BA2 & $5 \times 10^{-2}$ & 0.51 & 0.832154 & 0.9361729 & 1.040192 & 1.1442113 \\
BA3 & $5.1 \times 10^{-2}$ & 0.52 & 0.814726 & 0.9165671 & 1.018408 & 1.1202487 \\
BA4 & $4.8 \times 10^{-2}$ & 0.49 & 0.869511 & 0.9782 & 1.086889 & 1.1955778 \\
\hline
\end{tabular}

\section{Kesimpulan}

Berdasarkan penelitian ini maka dapat ditarik kesimpulan sebagai berikut:

1. Tanah sawah yang berada di Kelurahan Tarus Kabupaten Kupang mengandung P-tersedia tanah mulai dari range rendah hingga sangat tinggi sesuai dengan kriteria sifat kimia tanah Balai Penelitian Tanah Departemen Pertanian.

2. Tanah sawah yang berada di Kelurahan Tarus tersebut telah terkontaminasi dengan logam berat Cd dengan dosis tertinggi $1,79 \mathrm{mg}$ $\mathrm{kg}^{-1}$ dan dosis terendah $0,10 \mathrm{mg} \mathrm{kg}^{-1}$. Kandungan Cd pada tanah tersebut di pengaruhi oleh berbagai faktor lingkungan.

3. Beras yang dihasilkan dari lahan sawah di Kelurahan Tarus Kabupaten Kupang belum terkontaminasi oleh Cd yang melebihi ambang batas yang ada di dalam SNI 7387:2009 tentang batas maksimum cemaran logam berat dalam pangan sebesar $0,4 \mathrm{mg}$ $\mathrm{kg}^{-1}$.

4. Prediki risiko terhadap $\mathrm{Cd}$ pada beras menunjukan bahwa, $\mathrm{Cd}$ yang ada pada semua sampel beras sudah berisiko dikonsumsi selama tiga puluh tahun, sedangkan untuk durasi pajanan 20 tahun terdapat satu sampel beras yang sudah berisiko dan untuk durasi pajanan 15 tahun 
Yovita: Kandungan fosfor dan kadmium pada tanah dan beras serta risiko kadmium bagi kesehatan penduduk di kelurahan tarus

menunjukkan satu sampel beras yang masih aman untuk dikonsumsi karena nilai RQ kurang dari satu. Sampel lainnya yang terdeteksi Cd dalam beras masih berada di atas durasi default yaitu 30 tahun.

\section{Ucapan Terima Kasih}

Pada kesempatan ini penulis ingin mengucapkan terima kasih kepada semua pihak yang telah membantu dengan caranya masing-masing dalam melengkapi tulisan ini.

\section{DAFTAR PUSTAKA}

Ayeni, O. Ndakidemi, P. Snyman R.G. and Odendaal J.P. 2010. Chemical, Biological and physiological indicators of metal pollution in wetlands. Review. Sains Research and EAASy. Vol 5 (15).

ATSDR. 2005. ATSDR Public Health Assessment Guidance Manual. US Department of Health and Human Services.

[BPS]Badan Pusat Statistik. 2011. Kecamatan Kupang Tengah dalam angka. 2011. Kupang, NTT.

[BPT] Balai penelitian tanah, 2005. Petunjuk teknis analisis kimia tanah, tanaman, air dan pupuk. Badan penelitian dan pengembangan pertanian Departemen Pertanian

Codex Alementarius Commistion. 2001. Coments submitted on the draft guideline level and prosed drfatnmaximum level for cadmium. Codex committee on food additives and contaminants. Agenda item 16d, cx/FAC01/28. Thirty third seassion, 12-16
March, 2001. The Hague, the Netherlands. Joint FAO/WHO Food Standards Program. Rome, Italy.

Cotuk, Y. Belivermis, M. Kilic, O. 2010. Environmental Biology And Pathophysiology Of Cadmium. IUFS J Biol 69 (1): 15.

Charlena. 2004. Pencemaran Logam Berat Timbal $(\mathrm{Pb})$ dan Kadmium (Cd) pada sayur-sayuran. http://www.rudct.com/PPS702ipb/09145/Charlena.pdf

Duaja, W, 2006. Upaya Pengembangan Penerapan Teknologi Di Provinsi NTT. Makalah teknologi Mikoriza tingkat Provinsi NTT. Kupang.

enHealth. 2002. Environmental Health Risk Assessment: Guidelines for assessing human health risks from environmental hazards. Canberra:Commenwealth of Australia.

Gbaruko, B.C. and Friday, O. U. 2007. Bioaccumulation of heavy metals in some fauna and flora.

Gusnidar. 2007. Budidaya dan pemanfaatan Tithonia diversifolia untuk menghemat pemupukan $\mathrm{N}$, $\mathrm{P}$, dan $\mathrm{K}$ padi sawah intensifikasi. Disertasi Doktor. ProgramPasca sarjana, Universitas Andalas Padang. 256 hal.

Hadi, A. 2005. Prinsip Pengelolaan Pengambilan Sampel Lingkungan. PT.Gramedia Pustaka Utama, Jakarta.

Hardjowigeno, 2003. Ilmu Tanah. Akademika Pressindo, Jakarta.

IPCS] International Programme on Chemical Safety. 2004. Environmental Health Criteria XXX: Principles for modelling dose-response for the risk assessment of chemicals (Draft). Geneva: World Health 
Yovita: Kandungan fosfor dan kadmium pada tanah dan beras serta risiko kadmium bagi kesehatan penduduk di kelurahan tarus

Organization and International Programme on Chemical Safety.

[IPB] Institut Pertanian Bogor. 2006. Tinjauan Pustaka. http://iirc.ipb.ac.id/jspui/bitstream $/ 123456789 / 40756 / 3 /$ bab\%202/20 2006sa.pdf

Kauwenbergh, V,J,S. 2002. Cadmium content of phosphate rocks and fertilizer. International center of soil fertility and agricultural development. USA.

National Cd Minimisation Committee. 2003. Managing Cd in vegetables. VEGEnotes. July 2003.. Horticulture Australia. Sidney, NSW 2000, Australia.

Notodarmojo, Suprihanto. 2004. Pencemaran Tanah dan Air. Penerbit ITB, Bandung.

Novizan, 2002. Petunjuk Pemupukan Yang Efekif. Agromedia Pustaka, Jakarta.

Pratiwi,D., T.Jurniana., Kurniawati., K.Umi. 2008. Unsur Kadmium. http://himdikafkipuntan.blogspot. com/2008/05/cadmium.html.

Palar, H. 2004. Pencemaran tanah dan toksikologi logam berat. Rineka cipta, Jakarta.

Rahman, A. 2007. Public Health Assesment. Model kajian prediktif dampak lingkungan dan aplikasinya untuk manajemen risiko kesehatan. pusat kajian kesehatan lingkungan dan industry. Fakultas Kesehatan Masyarakat-Universitas Indonesia. Depok.

Ratnaningsih, A. 2003. Pengaruh Cd terhadap gangguan patologik pada hati tikus percobaan. Jurnal Matematika, Sains dan Teknologi Vol. 4,1, Maret 2003.

Rawat,S.K., R.K Singh., R.P Singh. 2012. Remediation of nitrite contamination in ground and surface waters using aquatic macrophytes. Jurnal Environtemtal Biol. 33:51-56.

Standar Nasional Indonesia. Nomor 7387. Tahun 2009. Batas maksimum cemaran logam berat dalam pangan.

Senn, A. and P. Milham. 2007. Managing cadmium in vegetables. New South Wales Department of Primary Industries.

Slamet, J.S. 2002. Kesehatan lingkungan. Gadjah Mada University Press. Yogyakarta.

Suwari. 2012. Analisis Risiko Kesehatan Lingkungan. Makalah disampaikan pada diskusi temu alumni PSL Institut Pertanian Bogor.

Szymezky, K. and Zalewski. 2003. Copper, Zinc and cadmium content in liver and muscles of Mallards and other hunting fowl spesies in warnia and Mazury in 1999-2000. J. Environ. 12 (3) ; 382-386.

Soemirat. $2000 . \quad$ Epidemilogi Lingkungan. Gajah Mada University Press. Yogyakarta.

Takashi, U. 2006. Pathogenesis of osteomalacia in itai-itai disease.

Uraguchi, S and Fujiwara, T. 2012. Cadmium transport and tolerance in rice: perspectives for reducing grain cadmium accumulation.

[WHO] World Health Organization. 2006. Bahaya Bahan Kimia pada Kesehatan Manusia dan Lingkungan. I.W. Palupi [Penerjemah]; E. Monica [Editor]. Terjemahan dari: Hazardous Chemicals in Human and Environmental Health. Published by WHO.

Winarso, S. 2005. Kesuburan Tanah Dasar Kesehatan dan Kualitas Tanah. Gava Media. Yogyakarta. 